\title{
薄膛トランジスター積層型ポリシリコン電子銃 アレイの製造方法及び電気特性
}

\begin{tabular}{|c|c|c|c|c|c|}
\hline 正 員 & 橋 & $\square$ & 原 & & (新日本製鉄) \\
\hline 非会員 & $\equiv$ & 村 & 秀 & 典 & (ATR光通研) \\
\hline 正 員 & 藤 & 田 & 博 & 之 & (東京大) \\
\hline
\end{tabular}

Fabrication and Electrical Characteristics of a Multi-layer Structure of Polycrystalline Silicon Field Emitters and Thin Film Transistor

Gen Hashiguchi, Member (Nippon Steel Corp.),

Hidenori Mimura, Non-member (ATR), and Hiroyuki Fujita, Member (The University of Tolsyo)

We have developed a new multi-layer structure of polycrystalline silicon field emitter array (poly-Si FEA) and thin film transistor(TFT), where poly-Si FEA and the TFT are successively fabricated using a thermally grown $\mathrm{SiO} 2$ mold and transferred to a glass substrate. During operation, the TFT not only controls amount of field emission but also stabilizes fluctuation of the field emission. Since the TFT does not decrease the space for poly-Si FEA fabrication, the structure will be a good candidate for high quality flat panel displays. In this paper, we present details of the fabrication method of the multi-layer structure, and also show the field emission control by the TFT for static and switching characteistics.

キーワード : 真空マイクロエレクトロニクス、TFT、ポリシリコン、電子銃、転写モールド

\section{1. まえがき}

近年、半導体微細加工技術を利用してミタロンサイズの 微小真空管や集積回路を作製しようとする真空マイクロ エレクトロニクスの研究が活発に行われている。この分 野にとって、均一で再現性が良い電子放出特性を持つ高 性能な冷電子銃アレイの開発が最優先の課題であり、こ れまでに種々の構造、材料の冷電子鋶アレイの開発が試 みられてきた。 [1-10] しかし、冷電子放出現象は、電子 銃表面の状態に極めて敏感であるため、電子銃の構造や 材料を選択しても、これだけで均一でかつ再現性のよい 冷電子放出特性を得ることは困難である。そこで、実際 は多数の冷電子銃をまとめてアレイ状とし、一つの冷電 子銃として動作させ、個々の冷電子銃の特性を平均化す ることによって、再現性及び均一性の確保を図っている。

一方、最近になって、冷電子銃アレイをトランジス夕等 の能動素子で形成した電流源で制御することにより、さ らに冷電子放出特性の改善を図る提案がなされた。 [11] この方法は、定電流源で放出電流量を制御するため、各
アレイ間で生じる電子放出特性のばらつきや、電子放出 特性の変動に起因する非安定性の改善に極めて有効であ る。また、電流源を構成するトランジス夕の駆動電圧で電 子放出を制御できるため、数 Vから十数 V程度の低い信 号電圧で朎電子銃アレイを制御できるという利点もある。 このため、冷電子銃アレイをトランジスタ等の能動素子 で形成した電流源で駆動することは、真空マイクロエレ タトロニタスにとって重要な技術であると考えられる。

我々は最近、マイクロマシーニング技術を利用して、杖 リシリコン冷電子銃アレイ (Poly-Si FEA:Polycrystalline Silicon Field Emitter Array) と薄膜トランジスタ( TFT:Thin Film Transistor）を積層した新しい構造の王 ノリシックデバイスを提案し，その試作を行ってきた。 [12] 本構造は、FEAの製造領域を削減することなく TFT が製造できるため、特に FEA の高密度形成が要求される 薄膜ディスプレイへの応用が期待できるものである。本 論文では、その製造方法について詳細に報告するととも に、実際に試作した TFT 積層型 Poly-Si FEA の電気特 性についても併せて報告する。 


\section{TFT 積層型 Poly-Si FEA の製造方法}

図 1に、我々が開発したTFT 積層型 Poly-Si FEA の 断面模式図を示す。図に示すように、ポリシリコン冷電 子銃アレイの下方に、TFT が TFT ゲート電極をガラス 基板側にして配置されている。そして TFT のドレインが Poly-Si FEA のエミッターに直接接続されている。最上 部の電子銃ゲート電極は、全ての Poly-Si 冷電子銃に対し て共通である。実際の動作は、電子銃ゲート電極に一定 の電圧を印加しておき、TFT のゲート電圧によって電子 放出を制御する。

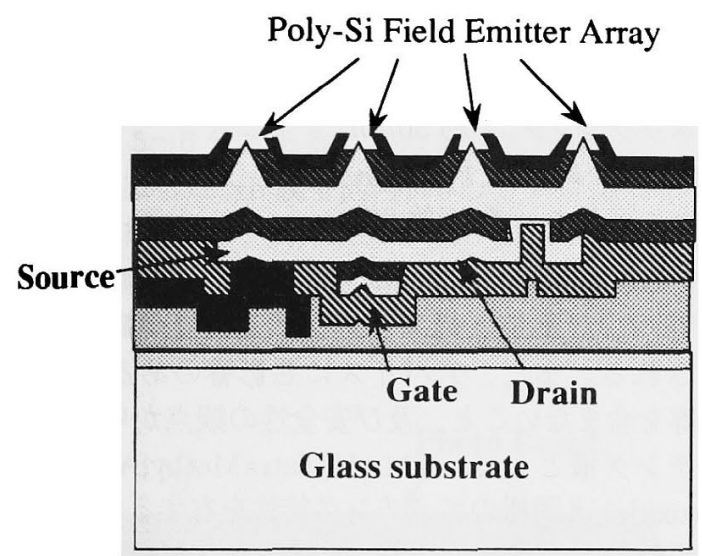

図 1 TFT 積層型 Poly-Si FEA の断面模式図

Fig.1. Schematic diagram of the multi-layer structure of a poly-Si FEA and TFT.

本構造の製造プロセスは大きくわけて次の 3 工程から なる。

・Si ウエハープロセス

・デバイス転写プロセス

・電子鋶ゲート電極形成プロセス

以下に各工程ごとに詳細に述べることとする。

〈2・1〉 Si ウエハープロセス Si ウエハープロセス は、Poly-Si FEA の形成 (A 工程) と、TFT の形成 (B 工程）からなる。ここでのプロセスはほは一般的な半導体 製造技術のみで行われる。図 2 に Si ウエハープロセスの 断面工程図を、表 1 にプロセス工程の詳細を示す。A工 程において Poly-Si FEA の鋳型は、 $\mathrm{KOH}$ 水溶液による 異方性エッチングを利用して形成している。エッチング マスクとしては減圧化学気層成長法 (LPCVD) で成膜し た SiN 膜を利用し、 $2.5 \mu \mathrm{m}$ 角の正方形の穴を $2.5 \mu \mathrm{m}$ 間隔 で形成したものを利用した。このエッチングにより、4つ の $\left\{\begin{array}{llll}1 & 1 & 1\end{array}\right\}$ 面が露出した正四角錐形状のエッチングホー ルが形成される。エッチング後に SiN 膜は、エッチング ホールにダメージが生じないように、HF 水溶液で除去し た。次に熱酸化を行い、膜厚 $200 \mathrm{~nm}$. $\mathrm{SiO} 2$ 膜の鋳型を 形成する。このようにして形成した鋳型は、冷電子銃形 成にとって非常に有効であり、高性能の FEA が試作され ている。 [13] その後 Poly-Si LPCVD で成膜し、n 型 (a)

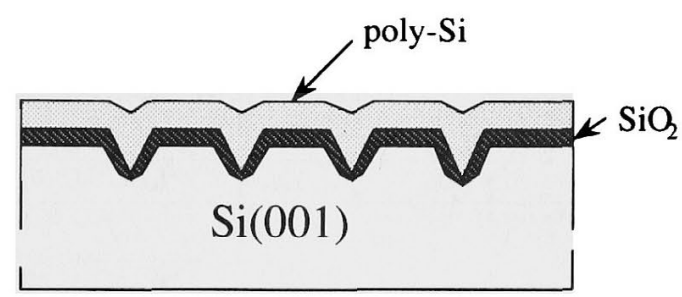

(b)
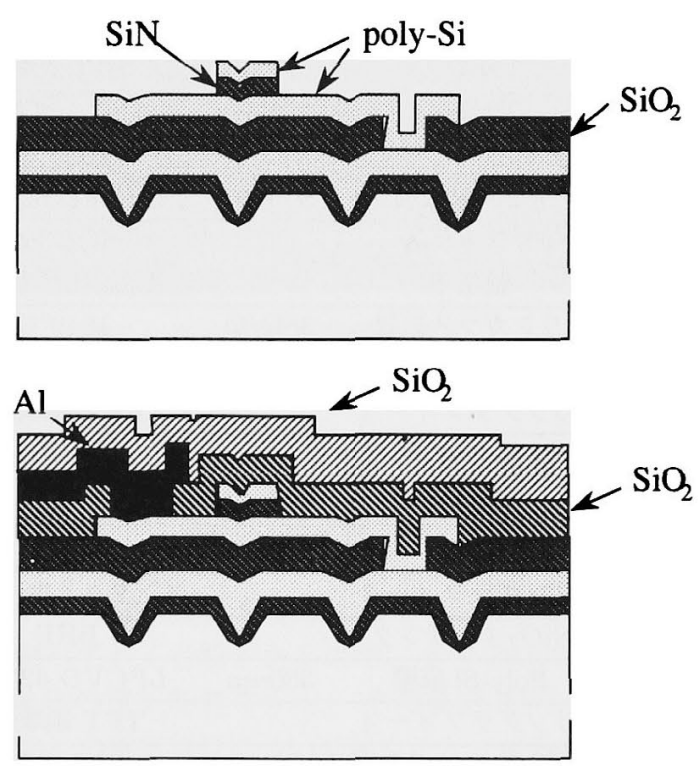

図 2 Si ウエハープロセスの工程断面図

Fig.2. Schematic diagram of the Si wafer processing.

にドーピングして Poly-Si FEA が形成される（図 2(a)）。 なお型ドーピングには、スピンコートによって形成さ れるリンガラス層（SOG）を拡散源とした。今回の試作 では、1つの Poly-Si FEA の領域は $600 \mu m \times 500 \mu m$ で あり、その中に 1 万個の泠電子銃が形成されている。

次に B 工程に抒いて TFT を Poly-Si FEA 上に形成す る。最初に Poly-Si FEA と TFT との層間絶縁膜である $\mathrm{SiO}_{2}$ 膜を LPCVD で成膜した後、Poly-Si FEA と TFT のドレイン電極とのコンタクトをとるためのコンタクト ホールをあける。次に Poly-Si 膜を LPCVD で成膜し、 TFT 領域となる Poly-Si アイランドを、フォトリソグ ラフィと反応性イオンエッチング（RIE）で形成する。 そして TFT のゲート絶縁膜である膜厚 $100 \mathrm{~nm}$ の $\mathrm{SiN}$ 膜と TFT ゲート電極となる膜厚 $200 \mathrm{~nm}$ の Poly-Si を LPCVD で連続的に成膜し、TFT ゲート電極のパターニ ングを行う。Poly-Si 膜は RIE でエッチングし、SiN 膜 は Poly-Si 及び $\mathrm{SiO}_{2}$ をッッングしないように、熱リン 酸を利用してエッチングした。ソース、ドレイン及びゲー トのドーピングはセルフアライン方式で、Poly-Si FEA 同様 SOG から拡散した。ゲート長、及びゲート幅はそ れぞれ $20 \mu m$ 及び $100 \mu m$ である。ゲート層のシート抵 
表 1 Si ウェハープロセスの工程フロー

Table.1. Si wafer process sequence

\begin{tabular}{|c|c|c|c|}
\hline \multicolumn{4}{|c|}{ A.Poly-Si FEA 形成工程 } \\
\hline & 工程名 & 膜旣等 & プロセス条件 \\
\hline 1 & $\mathrm{SiN}$ 成膜 & $50 \mathrm{~nm}$ & LPCVD $300^{\circ} \mathrm{C}$ \\
\hline 2 & リソグラフィー1 & & $\begin{array}{c}\text { エッチングホール } \\
\text { 形成用 }\end{array}$ \\
\hline 3 & SiN エッチング & & $\mathrm{RIE}: C F_{4}$ \\
\hline 4 & KOH エッチング & $6 \mathrm{~min}$ & $30 \mathrm{wt} \% 60^{\circ} \mathrm{C}$ \\
\hline 5 & SiN 除去 & & $\operatorname{HF}(25 \%)$ \\
\hline 6 & 熱酸化 & $200 \mathrm{~nm}$ & $\begin{array}{c}\text { バーニング酸化 } \\
1000^{\circ} \mathrm{C}\end{array}$ \\
\hline 7 & Poly-Si 成膜 & $500 \mathrm{~nm}$ & LPCVD $620^{\circ} \mathrm{C}$ \\
\hline 8 & $\begin{array}{c}\text { リンガラス } \\
\text { 膜塗布 }\end{array}$ & & $\begin{array}{c}\text { SOG 膜 } \\
\text { (東京応化社 OCD) }\end{array}$ \\
\hline 9 & リンガラス拡散 & $38 \Omega / \square$ & $1040^{\circ} \mathrm{C}$ \\
\hline 10 & リンガラス除去 & & $\mathrm{HF}(2.5 \%)$ \\
\hline 11 & リソグラ.フィー 2 & & FEA 領域用 \\
\hline 12 & Poly-Si エッチング & & $\mathrm{RIE}: C F_{4}$ \\
\hline 13 & $\mathrm{SiO}_{2}$ 成膜 & $500 \mathrm{~nm}$ & LPCVD $420^{\circ} \mathrm{C}$ \\
\hline \multicolumn{4}{|c|}{ B.TFT 形成工程 } \\
\hline 1 & リソグラフィー 3 & & コンタタトホール用 \\
\hline 2 & $\mathrm{SiO}_{2}$ エッチング & & $\mathrm{BHF}$ \\
\hline 3 & Poly-Si 成膜 & $300 \mathrm{~nm}$ & LPCVD $620^{\circ} \mathrm{C}$ \\
\hline 4 & リソグラフィー 4 & & TFT 領域用 \\
\hline 5 & Poly-Si エッチング & & $\mathrm{RIE}: C F_{4}$ \\
\hline 6 & $\mathrm{SiN}$ 成膜 & $200 n m$ & $\begin{array}{c}\mathrm{LPCVD} 420^{\circ} \mathrm{C} \\
\text { ゲート絶縁膜 }\end{array}$ \\
\hline 7 & Poly-Si 成膜 & $200 \mathrm{~nm}$ & LPCVD $620^{\circ} \mathrm{C}$ \\
\hline 8 & リソグラフィー 5 & & ゲートパターン用 \\
\hline 9 & Poly-Si エッチング & & $\mathrm{RIE}: C F_{4}$ \\
\hline 10 & $\mathrm{SiN}$ エッチング & & $\begin{array}{c}\mathrm{H}_{3} \mathrm{PO}_{4} \\
160 \sim 170^{\circ} \mathrm{C} \\
\end{array}$ \\
\hline 11 & リンガラス成膜 & & $\begin{array}{c}\text { SOG 膜 } \\
\text { (東京応化社 OCD) }\end{array}$ \\
\hline 12 & リン拡散 & & $1040^{\circ} \mathrm{C}$ \\
\hline 13 & $\mathrm{H}_{2}$ プラズマ処理 & 5hour & $300^{\circ} \mathrm{C}$ \\
\hline 14 & $\mathrm{SiO}_{2}$ 成膜 & $500 \mathrm{~nm}$ & PECVD $250^{\circ} \mathrm{C}$ \\
\hline 15 & リソグラフィー6 & & $\begin{array}{c}\text { ソース電極 } \\
\text { コンタクト用 }\end{array}$ \\
\hline 16 & $\mathrm{SiO}_{2}$ エッチング & & BHF \\
\hline 17 & $\mathrm{Al}$ 成膜 & $500 \mathrm{~nm}$ & $\mathrm{~EB}$ 蒸着 $150^{\circ} \mathrm{C}$ \\
\hline 18 & リソグラフィー7 & & ソース電極用 \\
\hline 19 & $\mathrm{Al}$ エッチング & & $\mathrm{H}_{3} \mathrm{PO}_{4} 50^{\circ} \mathrm{C}$ \\
\hline 20 & $\mathrm{SiO}_{2}$ 成膜 & $500 \mathrm{~nm}$ & PECVD $250^{\circ} \mathrm{C}$ \\
\hline
\end{tabular}

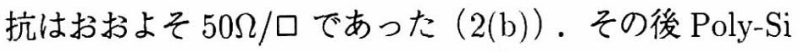
膜の水素化処理のため、水素プラズマを $300^{\circ} \mathrm{C}$ において 5 時間照射した後、引き続き $\mathrm{SiO}_{2}$ 膜を $500 \mathrm{~nm}$ 成膜し、 ソース電極用コンタクトホールを開けた後、 $\mathrm{Al}$ を電子 ビーム蒸着法により成膜する。 $\mathrm{Al}$ パターニングの後、最 後に再び PECVD でパッシーベーション用 $\mathrm{SiO}_{2}$ を成膜 する $(2(\mathrm{c}))$.
〈2・2〉 デバイス転写プロセス＼cjkstart形成された Poly-Si FEA と TFT は次にガラス基板上に転写される。一般に 凹凸のない $\mathrm{Si}$ 基板とガラス基板の接合には、陽極接合 による接合が利用されるが、デバイスを形成した $\mathrm{Si}$ 基 板表面は凹凸が大きいので、我々はエポキシ樹脂系接着 剤（セメダイン社製、室温 30 分硬化型）を利用してパイ レックスガラス（CORNING7740）との接着を行った。 ここでは気泡が接着凨中に残らないことが重要である。

次に $\mathrm{Si}$ 基板（厚さ約 $400 \mu \mathrm{m}$ ）を全て除去する。この 除去の工程は次に示す 4 つの工程からなり、各工程での おおよその Si 基板除去量もあわせて示す。

・グラインダー：約 $300 \mu m$

・ポリッシング : 約 $50 \mu m$

- $\operatorname{RIE}\left(C F_{4}\right)$ : 約 $30 \mu \mathrm{m}$

・ウエットエッチ：約 $20 \mu \mathrm{m}$

最後のウエットエッチング工程では、 $\mathrm{SiO}_{2}$ 膜鋳型の保 護のため、 $\mathrm{Si}$ 基板とのエッチング選択性が高いことが 要求される。また、デバイスに悪影響のあるアルカリ 金属等を含まないこと、及び安全性の観点から、我々性 エッチング液として、TMAH(TetraMethylAmmonium Hydroxide) と同梯のエッチング特性を有するポジレジス 卜用現像液 (東京応化社製、NMD-3、6 $5^{\circ} \mathrm{C}$ ) を利用し た。このエッチング液はエポキシ接着剤もほとんど変質 させない。

以上の工程で、Poly-Si FEA 及び TFT はガラス基板上 に転写される。図 3 にガラス基板に転写後の TFT 積層 型 Poly-Si FEA の光学顕微鏡写真を示す。格子状に小さ く見える点が、Poly-Si FEA であり、その下にTFT が 形成されているのが観察できる。

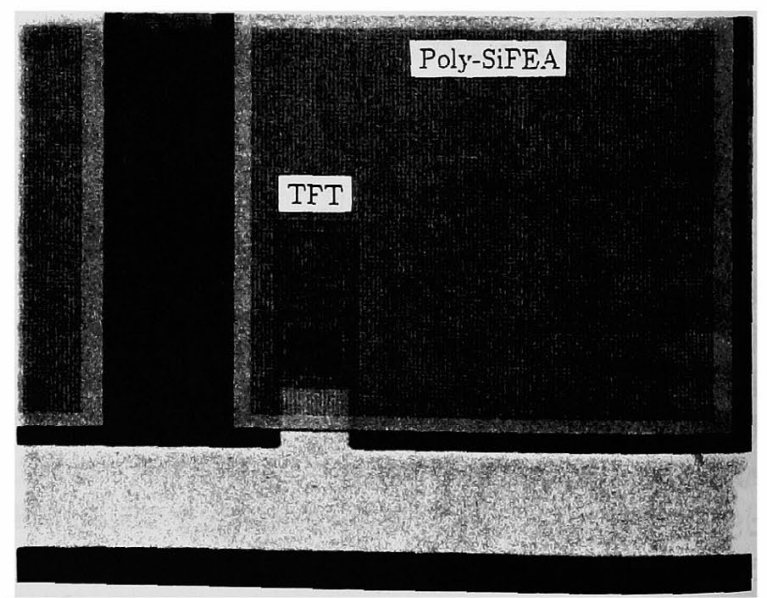

図 3 ガラス基板に転写後の TFT 積層型 Poly-Si FEA の光学顕微鏡写真

Fig.3. Photograph of the transfered device on a glass substrate.

$\langle 2 \cdot 3\rangle$ 電子銃ゲート電極形成プロセス 転写後の デバイス表面は、 $\mathrm{SiO}_{2}$ の鋳型が露出しており、最後に 
鋳型上に電子銃用ゲート電極を形成してデバイスは完成 する。

図 4に電子銃ゲート電極の断面工程図を示す。まず $\mathrm{SiO}_{2}$ 鋳型上に、電子銃ゲート電極材料である膜厚 $200 \mathrm{~nm}$ の $\mathrm{Nb}$ をスパッタリング法により形成する。次に各冷電 子銃の先端部を露出させるために、鋳型先端部の $\mathrm{Nb}$ 膜を レジストを利用したエッチバック法により除去する。レ ジストは微小な凹凸部があっても、図 $4(\mathrm{a})$ に示すように 凹凸部を平坦化するように形成される。この表面を徐々 にエッチングしていくと、凸部を優先的にエッチングで きる。我々はフォトレジストを約 $1 \mu \mathrm{m}$ の厚さになるよう にスピンコートし、RIE によってエッチバックを行った。 $\mathrm{RIE}$ 条件は $C F_{4}$ ガス、20Pa、 $400 \mathrm{~W}$ であり、エッチバッ ク時間は約 5〜6 分である。このレジストエッチバック により、露出した Nb 膜も同時にエッチングされる（図 4(b)）。最後に冷電子銃先端部の $\mathrm{SiO}_{2}$ 膜を、エッチバッ クにより形成された $\mathrm{Nb}$ 膜の電子銃ゲート開口部を通し て、BHF で除去することにより Poly-Si FEA を露出さ せた。

(a)

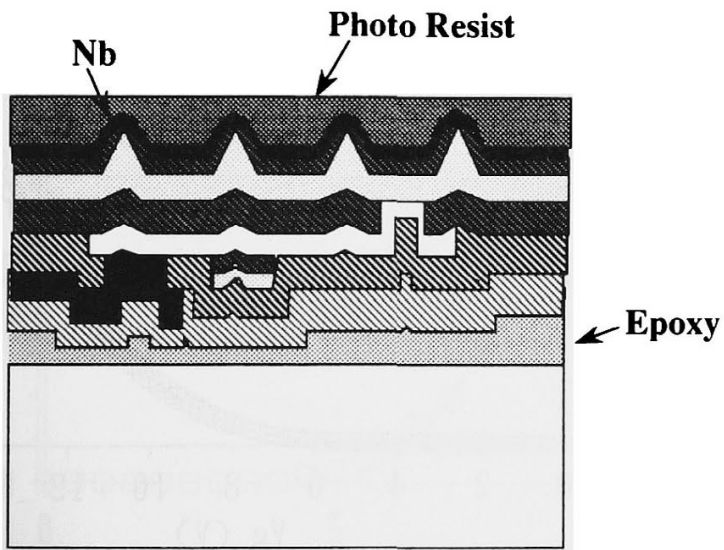

(b)

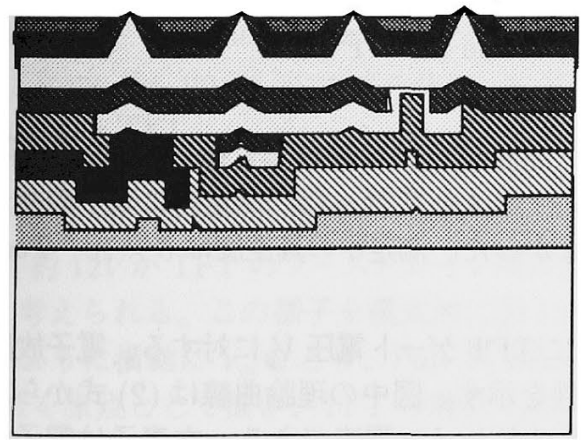

図 4 電子銃ゲート電極形成プロセスの工程断面図

Fig.4. Schematic diagram of the gated structure fabrication.

図 5に、上記プロセス終了後の Poly-Si FEA の電子顕 微鏡写真を示す。 $\mathrm{Nb}$ 膜の電子銃ゲート構造の中心部に
Poly-Si FEA が観察できる。

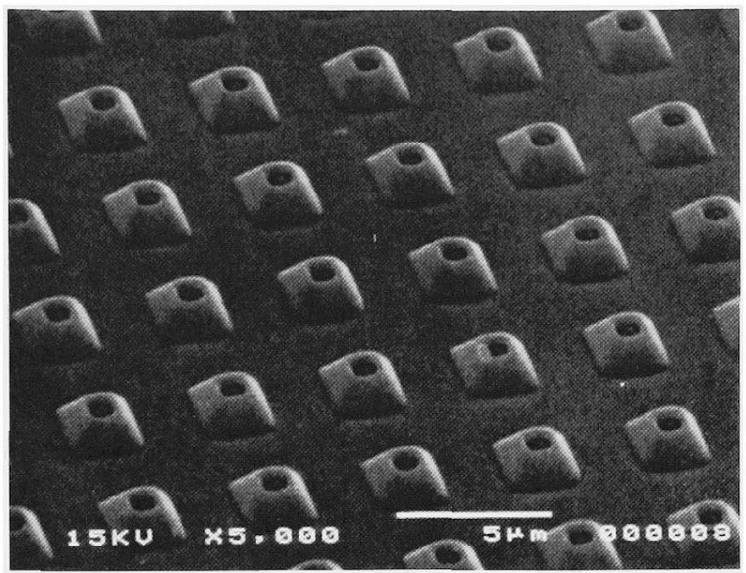

図 5 Poly-Si FEA の走査電子顕微鏡写真

Fig.5. SEM micrograph of the poly-Si FEA.

\section{TFT 積層型 Poly-Si FEA の電気特性}

今回の試作においては、Poly-Si FEA と TFT を分離 した形のテスト素子を同時に形成した。TFT 積層型 Poly-Si FEA の電気特性を把握するためには、個別の電 気特性を調べておく必要があるので、まず Poly-Si FEA と TFT 単体の電気特性を示し、その後で TFT 積層型 Poly-Si FEA の電気特性について示すこととする。

〈3.1〉 Poly-Si FEA の電子放出特性 図6にテス トPoly-Si FEA の電子放出電流 $\left(I_{\epsilon}\right)$ に対する電子銃 ゲート電圧 $\left(V_{g e}\right)$ 依存性を示す。測定時の真空度は約 $5 \times 10^{-7}$ Torr、アノード電圧 $V_{a}$ は $100 \mathrm{~V}$ である。図に 示すように $V_{g e}=38 \mathrm{~V}$ のき約 $10 \mu \mathrm{A} 、 V_{g e}=45 \mathrm{~V}$ で約 $51 \mu A$ の電子放出電流が得られた。図 7 に上記特性の ファウラーノルドハイム (Fowler-Nordheim) プロットを 示す。ここで得られた傾きは、以前我々が報告した 512 個の冷電子銃からなる Poly-Si FEA [13] とほほ同じで あった。

一般に電子放出特性は次式で近似できる。(1)

$$
I_{e}=a V_{g e}^{2} \exp \left(-b / V_{g e}\right)
$$

ここで $a$ は定数であり、一 ムプロットの傾きである。図 6、及び図 7より本 Poly-Si FEA では、 $a \approx 7.0 \times 10^{-4} A / V^{2} 、 b \approx 3.6 \times 10^{2} V$ と算出 される。

〈3.2〉 TFT の静特性 図 8にテスト用 TFT の、 TFT ゲート電圧 $\left(V_{g}\right)$ をパラメータとしたソース・ドレ イン間電圧 $\left(V_{d s}\right)$ に対する、ドレイン電流 $\left(I_{d}\right)$ の依存 性を示す。 $V_{g}$ は $0 \mathrm{~V}$ から $2 \mathrm{~V}$ ステップで $10 \mathrm{~V}$ まで変化さ せた。罒に示すように、一般的な MOS (Metal-OxideSemiconductor) 構造のトランジスタと同様の静特性が 得られた。図9には $V_{g}$ に対する $I_{d}$ の依存性を示す。この 特性をよく知られている MOS トランジスタの飽和領域 におけるドレイン電流の理論式 [14] 


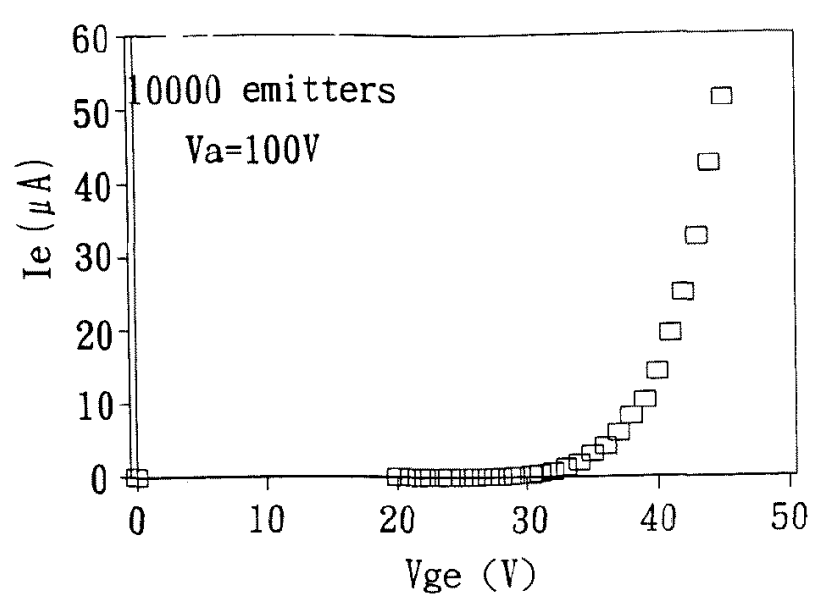

図 6 テスト用Poly-Si FEA の電子銃ゲート電圧 (Vge) に対する電子放出電流 (Ie) 特性

Fig.6. Gate voltage (Vge) dependence of the emission current (Ie) from the test poly-Si FEA.

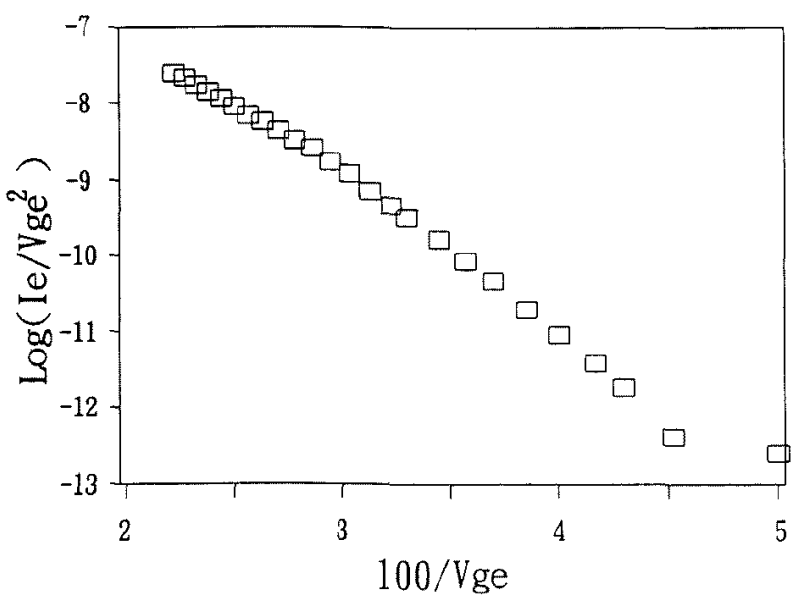

図 7 図 6 の電子放出特性に対するファウラーノルドハ イム (Fowler-Nordheim) プロット

Fig.7. Fowler-Nordheim (F-N) plot of Fig.6.

$$
I_{d}=\mu \epsilon W\left(V_{g}-V_{t h}\right)^{2} / 2 t L
$$

で近似する。ここで $\mu$ は電界効果移動度、 $\epsilon$ 及び $t$ は ゲート絶縁膜の誘電率及び膜厚、W及び $L$ はチャネル 長及びチャネル幅、V、化はしきい値である。本 TFT では $\mu \approx 2.78 \mathrm{~cm}^{2} / \mathrm{V} \cdot s 、 V_{t h} \approx 5.0 \mathrm{~V}$ 程度であった。

〈3.3〉 TFT 积居型 Poly-Si FEA の電子放出特性 次に TFT 積層型 Poly-Si FEA の電子放出特性を示す。 本素子では、電子放出の制御はモノリシックに形成され たTFT ゲート電圧によって行われる。図 10 に測定シス テムの模式図を示す。電子銃ゲート電極 $V_{g e}$ 及びアノード 電極 $V_{a}$ には、それぞれ $50 \mathrm{~V}$ 及び $100 \mathrm{~V}$ 定電圧が印加し てある。TFT ダート電極には保護のため $R_{g}=1 M \Omega の$ 抵抗を通して電圧を印加した。電子放出電流の測定は、

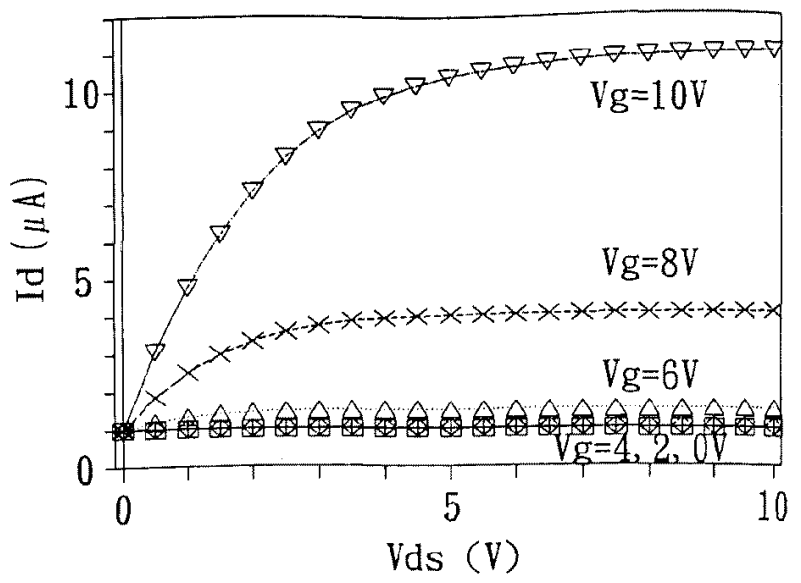

図 8 テスト用 TFT のソースドレイン間電圧 $(\mathrm{Vds}) に$ 対する、ドレイン電流依存性

Fig.8. Source-drain voltage (Vds) dependence of the drain current (Id) of the test TFT.

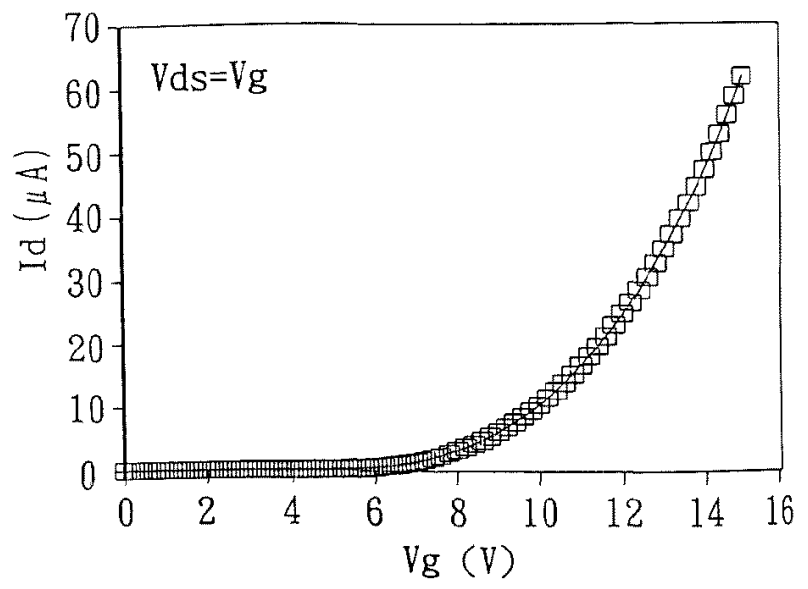

図 $9 \mathrm{TFT}$ ゲート電圧 $(\mathrm{Vg})$ に対するドレイン電流 (Id) 特性

Fig.9. Gate voltage $(\mathrm{Vg})$ dependence of the drain current (Id) of the test TFT.

アノード電極に直列に接続した抵抗 $R_{a}$ の電圧降下を測 定することによって行った。測定前に素子のベーキング は行わなかった。測定中の真空度は $5 \times 10^{-7}$ Torr以下で ある。

図 11 KFT ゲート電压 $V_{g}$ に対する、電子放出電流 $I_{a}$ の依存性を示す。図中の理論曲楾は (2) 式から計算され る TFTのドレイン電流である。本素子は電子銃ゲート 電極の電流は、 $n A$ オーダーでは観測されず、TFT を流 れるドレイン電流のほとんどが電子放出電流として睻 されていると考えられる。本素子は $V_{g}=10 \mathrm{~V}$ 時、約 $10 \mu \mathrm{A}$ の電子放出が観測されているが、Poly-Si FEAの 特性が 3.1 節の 6で述べた Poly-Si FEA と同程度である 


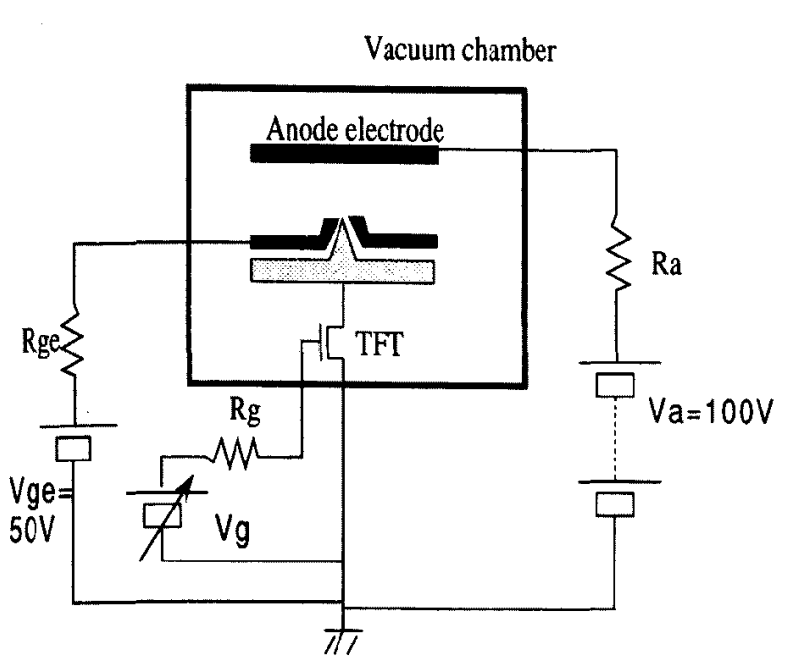

図 10 測定システムの模式困

Fig.10. Schematic of the emission characteristic measurement system used in this study.

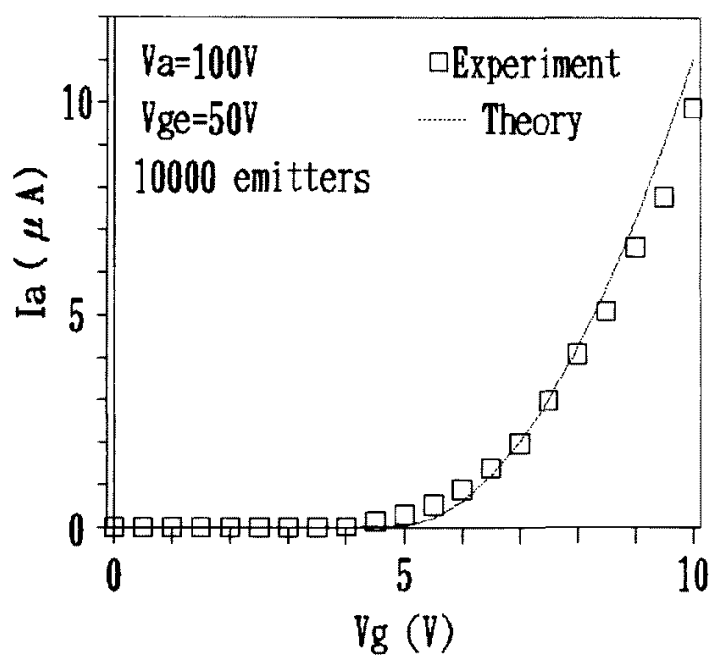

図 $11 \mathrm{TFT}$ ゲート電圧 $(\mathrm{Vg})$ に対する電子放出電流 (Ia) の依存性

The gate voltage $(\mathrm{Vg})$ dependence of the emission current (Ia) from the multi-layer structure of the polySiFEA and the TFT.

と仮定すれば、 $V_{g e}=50 \mathrm{~V}$ の電圧のうち䄪 $38 \mathrm{~V}$ が Poly-Si FEA に、約 $12 V$ がTFT のソースドレイン間に分配され ていると考えられる。この样子を模式的に図 12 に示す。 図に示すように横軸に $V_{g e}$ をとり、Poly-Si FEA の特性 $I_{e}$ を $V_{g e}$ 点を原点として描き、TFT の特性 $I_{d}$ は $0 V$ の点 を原点として描けば、その交点における電流值 $I_{a}$ が動作 点となっていると考えられ、ここが $V_{g e}$ の分圧点となって いると推測される。ここで動作点が、TFT の飽和電流領 域であるかあるいは線形電流領域であるかは、 $V_{g e} に$ 対す る電子放出特性を測定す机ば推定できる。すなわち、例 えば現在の動作点が図 12中の $I_{a}$ 点にあるとすれば、 $V_{g e}$
を低い電圧にしていくと、電子放出電流 $I_{e}$ の特性は図に 示すように左側に並行移動し、 $I_{d}$ との交点が TFT の飽和 電流領域から線形領域にはいり、図中のI $I a^{\prime}$ 点のように 電子放出電流が小さくなってくると考方られる。図 13 に電子銃用ゲート電極電圧 $V_{g e}$ に対する電子放出電流の依

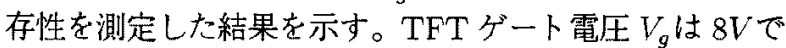
ある。 $V_{g e}$ が $45 V$ 以上では、TFT の飽和電流領域で動作 し、40V以下では線形領域での動作になっていると考之 られる。そして電子放出は $V_{g e}$ が $30 V$ 以下ではほとんど 観測されなくなっているが、これは图 6に示したように、 今回試作した Poly-Si FEA の電子放出の開始電圧が $30 \mathrm{~V}$ 程度であることに対応していると考えられる。

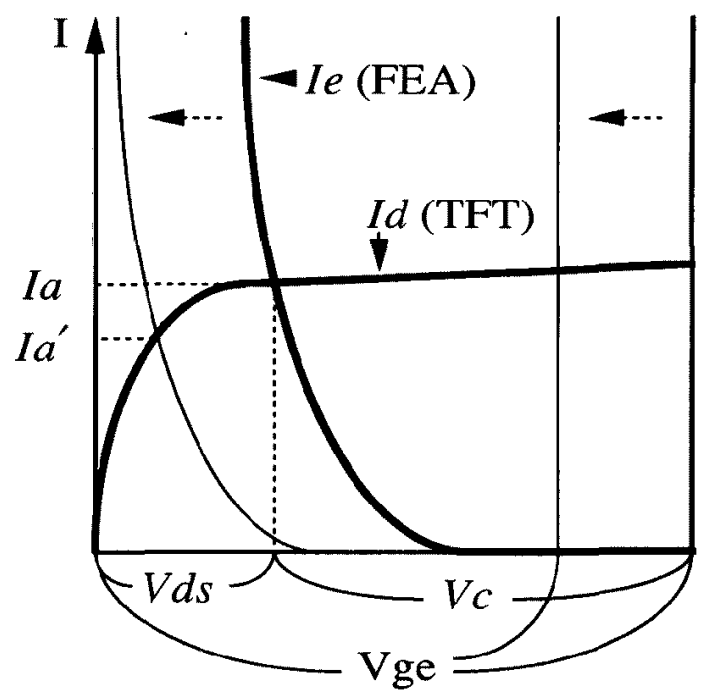

図 12 TFT 積層型 Poly-Si FEA の動作点を表す模式図 Fig.12. Schematic diagram of the operation

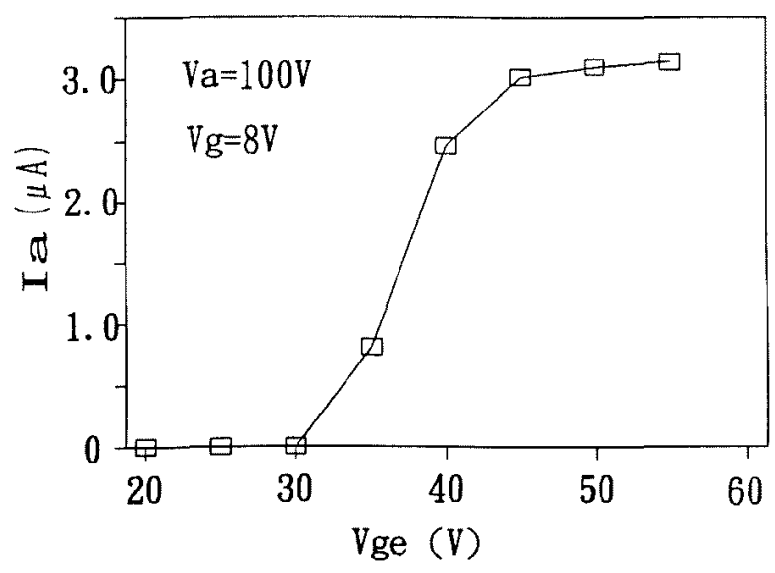

図 13 電子銃ゲート電圧 (Vge) に対する電子放出電流 (Ia) の依存性

Fig.13. Field emitter gate voltage (Vge) dependence of the emission current ( $\mathrm{Ia}$ ). 


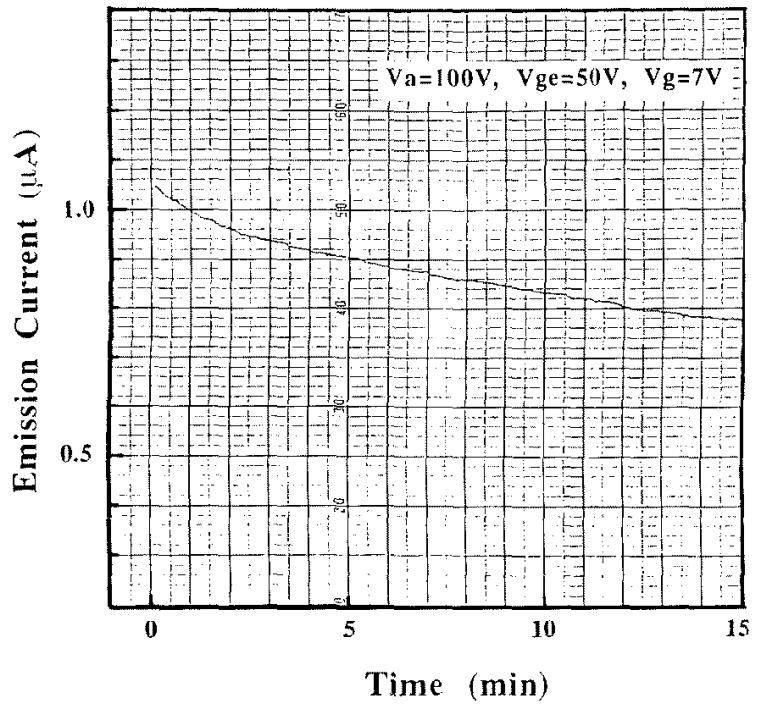

(a)

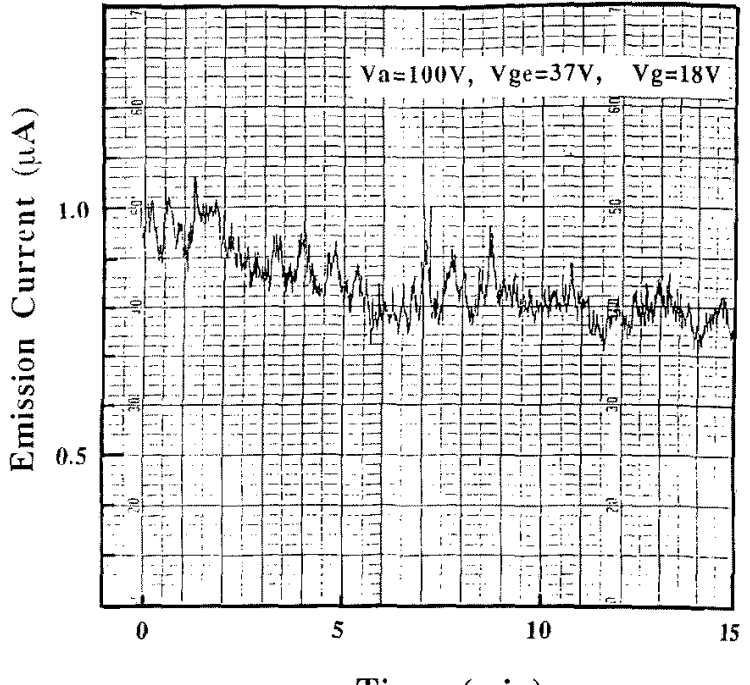

Time (min)

(b)

図 14 TFT 積層型 Poly-Si FEA の電子放出電流の時間変動

（a）動作点が TFT の飽和電流領域内にある場合、(b) 動作点が TFT の線形電流領域内にある場合

Fig.14. Emission fluctuations of the poly-Si FEA. The TFT was operated in (a) the satulation current region and (b) the linear current regions.

$\langle\mathbf{3 . 4 \rangle}$ 電子放出電流の時間変動 3.3 節で述べたよ うに、TFT 積層型 Poly-Si FEA では、TFT の館和電流 領域が動作点であれば、冷電子銃の特性が多少変動した としても、TFTを流れ西電流はほとんど変化しないた め、電子放出電流の変動は抑えられるはずである。一方、 TFT の線形電流領域では、冷電子銃の特性が変化する と、TFT 流れる電流当変化し、結局電子放出電流も変 動するはずである。図 $14 k T F T$ T電子放出を制御しな がら測定した、電子放出電流の時間変動を示す。(a) 図 は、 $V_{a}=100 \mathrm{~V} 、 V_{y c}=50 \mathrm{~V} 、 V_{g}=7 \mathrm{~T}$ の条件で測定し たものであり、この時の動作点は、TFT の飽和電流領 域内にあると考えられる。また(b) 図は、 $V_{a}=100 \mathrm{~V} 、$ $V_{g e}=37 V 、 V_{g}=18 V$ の条件で測定したものであり、動 作点はTFTの線形電流領域内にあるものと考えら机る。 (a) 図、(b) 図とも、電子放出電流は全体として徐々に減 少していき、それに速い変動成分が重なって観測されて いる。我々は徐々に減少する変動については、(1) テスト 用 TFT 単体においても、同様のドレイン電流の減衰が観 測されること、(2) TFT のゲートに負電圧を印加してお くことによって、電子放出電流がほとんど初期の電流值 まで回復すること、の 2 点から TFT の䦨値が高い方へシ フトしたために TFTを流れるドレイン電流が減少したた めと考之ている。一方、速い変動成分は、電子放出電流 本来の変動成分と考えられ、(b) 図では最大 $200 \mathrm{nA}$ 程度 の振幅を持つ変動が観察されているが、(a) 図では $10 \mathrm{nA}$ 以下まで変動が抑えられているのが分かる。以上の結果
から、TFT1 個からなる電流制御方法においても、十分 変動の抑制に有効であることか確認された。

\section{TFT 積層型Poly-Si FEA のスイッチング特性}

TFT 皘層型 Poly-Si FEA の Poly-Si FEA 部分は、電 子銃ア゙ート電極と電子銃が平行平板型のコンデンサーを 構成している。3.3節の議論からも推察されるように、実 際の電子放出の制御は、このコンデンサー容量の充放電 によって行われていると考えられ、交流駆動を議論する 場合は、その容量の充放電を考慮しなければならない。 ここでは方形状パルス電圧でTFT をスイッチングしたと きの電子放出電流のシミュレーション、及び実際に得ら れたスイッチング特性について述べこととする。

〈4.1〉 スイッチング特性シミュレーション 我々 は次の 2 つ仮定のもとでシミュレーションを行った。

1. FEA は、コンデンサー容量 $\left(C_{g e}\right)$ と電流源 $\left(I_{e}\right)$ で表 現され、 $I_{e}$ は $C_{g \mathrm{e}}$ の充電電圧 $\left(V_{c}\right)$ によって制御され るファウラーノルドハイム型電流源である。

2. TFT は $V_{g}>V_{i h}$ において、理想的な電流源 $\left(I_{d}\right)$ で 表現できる。

上記仮定のもとで得られる TFT 積層型 Poly-Si FEA の等価回路を図 15 に示す。図に示すように $C_{g e}$ と2つの 電流源 $I_{e}$ 及び $I_{d}$ は A 点 (TFTのドレイン電極) で接繶 され、 $C_{g e}$ と電流源 $I_{e}$ のもう一方の電極はそれぞれ $V_{g e}$ と $V_{a}$ へ接続され、そして電流源 $I_{d}$ のもう一方の電極は接地 されている。この等価回路の $\mathrm{A}$ 点に扔けるキルヒホッフ 
の第1法則による電流の式は次式のように書ける。

$$
\begin{aligned}
& C_{g e} \frac{d V_{c}}{d t}+a V_{c}^{2} \exp \left(\frac{-b}{V_{c}}\right)=I_{d}\left(V_{g}>V_{t h}\right) \cdots \cdots \\
& C_{g e} \frac{d V_{c}}{d t}+a V_{c}^{2} \exp \left(\frac{-b}{V_{c}}\right)=0\left(V_{g} \leq V_{t h}\right) \cdots \cdots
\end{aligned}
$$

ここで $I_{e}$ の表式として（1）式を利用した。

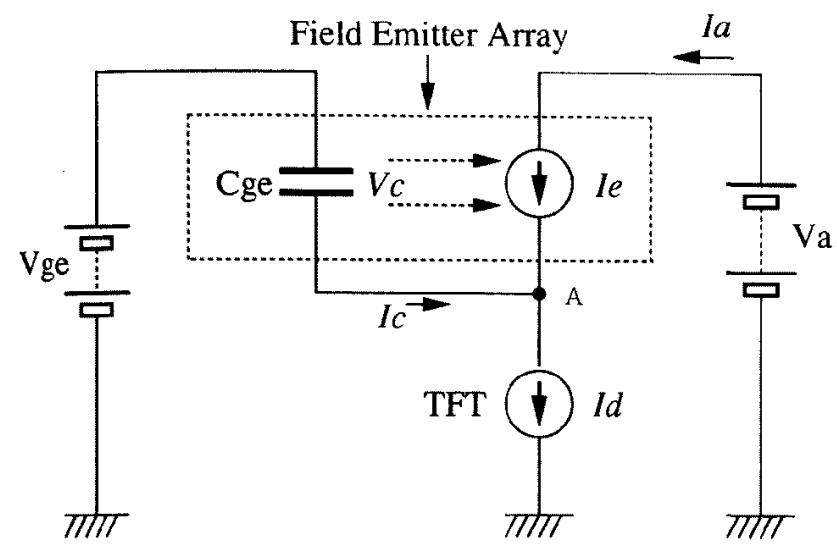

図 15 TFT 積層型 Poly-Si FEA の理想化された等価回 路

Fig.15 Equivalent circuit of the poly-Si FEA on TFT.

実際のシミュレーションでは、定数 a 及びbには 3.1 節で実験的に得られた值、そして $C_{g c}$ にはプロセス設計值 である約 $60 p F$ を代入して、(3) 式、及び (4) 式より数值 的に $V_{c}$ を計算し、次に (1) 式上り電子放出電流 $I_{a}$ 算出 した。図16に電子放出電流のシミュレーション結果を示 す。波線の波形は $I_{d}$ のパルス電流波形を表しており、パ ルス周波数 $1 k H z, 5 k H z 、 10 k H z k$ 拈り電子放出電流 の計算結果を示してある。 $1 k H z に お け る$ 電子放出電流は 比較的もとの $I_{d}$ の波形と同様の波形を示しているが、 $I_{d}$ と同レベルまで立ち上がるのに若干の時間遅れを生じ、 また $I_{d}=0$ (TFT がオフ）の期間においても電子放出電 流が流れることが分かる。これらは $C_{g e}$ の充放電現象とし て理解される。すなおち、立ち上がりにおいては、 $I_{d}$ と 同し電子放出電流を得るために必要な電圧まで、C $C_{g e}$ を昇 圧するための充電期間が必要であり、そして立ち下がり においては、充電されたキャリアを電子放出電流として 放出しながら $C_{g e}$ を降圧するための放電期間が存在してい る。従って $I_{d}$ のパルス周波数が高くなり、パルス間の間 隔が短くなってくると、充放電が充分行われないうちに

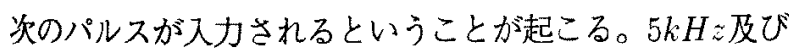

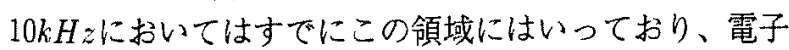
放出電流の波形は振幅も小さくのこきり波のようになり、 電子放出が完全にオンオフされないことが予測される。

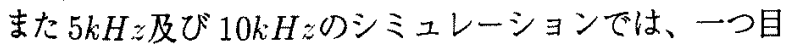
の入力パルスにおける電子放出電流は以後の特性とは異 なり、波形が完全に立ち上がっていない。これは $C_{g e}$ の 初期の電圧値に強く依存しており、何らかの原因で $C_{g e}$ に
リークがあって充電電圧が下がってしまうような場合で は、1つのパルス入力だけでは充分な充電ができず、電 子放出電流が流れないようなことが予測される。
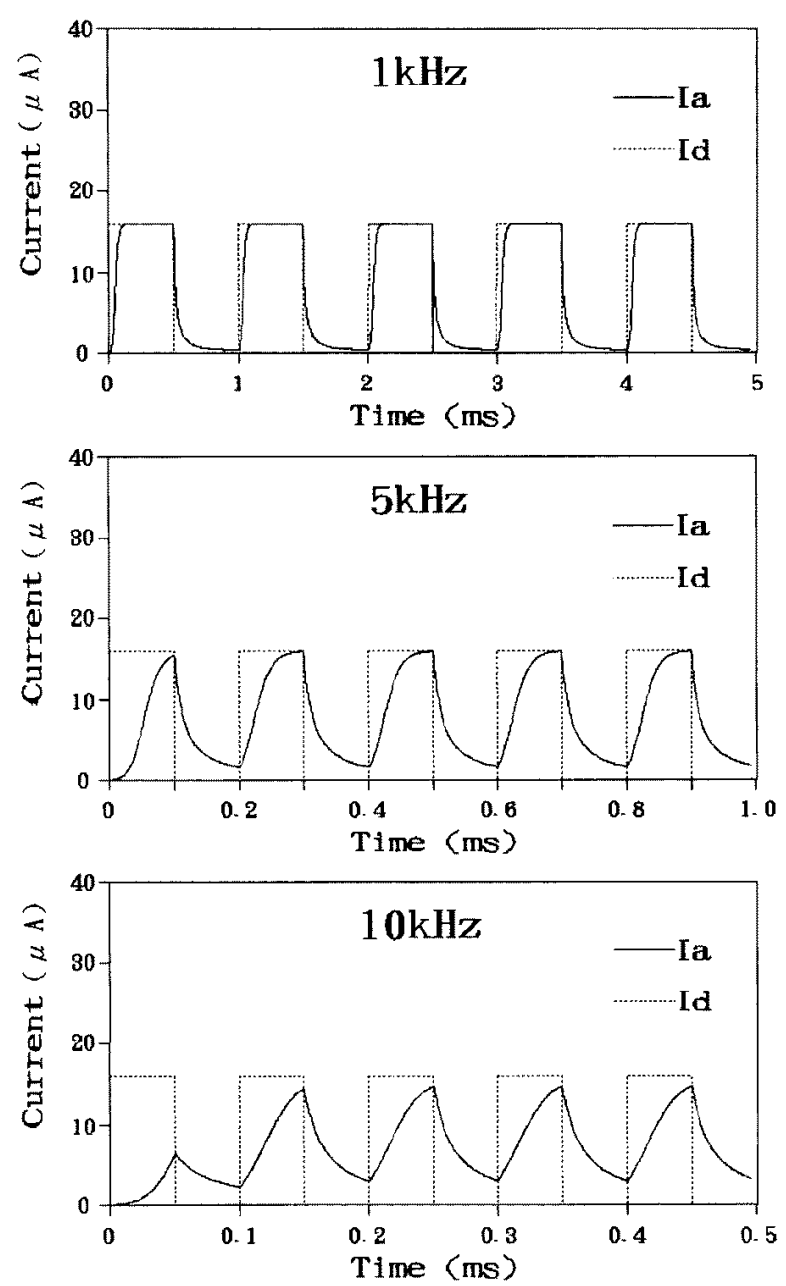

図 16 方形波パルスで駆動したときのシミュレーション 結果

Fig.16. Simulation results for the pulse driving.

〈4·2〉 スイッチング特性測定結果 図 17に夷測

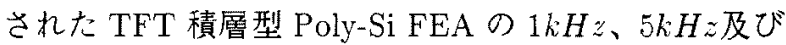
$10 k H z$ に扔けるスイッチング特性を示す。各図中上部 の波形はスイッチング電压の波形（TF Tにはさらに1 段インバーターを介してパルス電圧を入力）であり、下 部の波形はアノード電極における交流電位を示しており、 $1 k H \approx k$ にりる電子放出電流の振幅は約 $15 \mu \mathrm{A}$ である。図 $10 に$ 示したように、本測定回路では抵抗 $R_{a}$ で電圧降下を 生じさせているので、アノード電極における交流電位は $V_{g}$ に印加した電圧とは逆位相で観測されている。実測さ れた波形は図 16に示した対応する周波数におけるシミュ レーション波形とよく一致しており、また振幅も周波数 が高くなるにつれてシミュレーションで予測されたよう に小さくなっていることが分かり、完全に電子放出がオ 
ンオフされていないことが理解される。

今回作製した素子では、Poly-Si FEA 部の容量が約 60pF であるが、さらに高速なスイッチング特性が要求 される場合は、鋳型の酸化膜を厚くしたり、電子銃ゲー 卜電極のパターンを工夫するなどして容量を小さくすれ ば、10kHzにおいても、例えば $10 p F$ まで容量を減らせ ば、図 16 中の $1 \mathrm{kHz}$ と同様の電子放出パターンが得られ ることがシミュレーションで予測される。さらに容量を 小さくすることも可能であり、動画を表示するデイスプ レイヘも十分応用できると考えている。

\section{5. まとめ}

以上我々が開発した TFT 積層型 Poly-Si FEA につい て、その製造方法及び電気特性を詳細に述べた。本製造 法では Poly-Si FEA の形成には鋳型を利用した転写法 を採用し、Poly-Si FEA 上に連続して TFT を形成する プロセスであるため、Poly-Si FEA と TFT の製造プロ セスの整合性については、全く問題にならない。試作し た TFT 積層型 Poly-Si FEA の電子放出特性は、TFTに よって制御されており、電子放出自体を起源とする変動 成分の安定化にも有効なことが確認された。また電子放 出のスイッチング特性は Poly-Si FEA 構造の有する平行 平板コンデンサーの容量の充放電速度によって支配され ていることが、シミュレーション及び実測データにより 理解された。

本構造及び製造方法は、微小立体構造物とそれを制御す るための電子回路を 3 次元的に形成するための一つの手 段として、FEA の制御のみならず、いわゆる微小電気機 械システム（MEMS）のインテリジェント化への応用 も充分可能であると考えている。

\section{謝辞}

本研究の素子製造において、技術的な援助、助言をいただい た新日鉄先端技術䂙究所大沢保氏に深く感謝いたします。また 本研究全般について支援をいただいた、新日鉄先端技術研究所 半導体基盤研究部車田克彦部長、同大谷界主任研究員、及び同 太田泰三主任研究員に深く感謝いたします。

(平成 7 年 11 月 22 日受付、平成 8 年 2 月 5 日再受付)

$$
\text { 文献 }
$$

(1) C.A.Spindt, I.Brodie, L.Humphrey and E.R. Westerberg:"Physical properties of thin film field emission cathodes with molybdenum cones", J.Appl.Phys. 47,5248(1976).

(2) H.H.Busta, B.J.Zimmerman, M.C.Tringides, and C.A.Spindt:"DC I-V Characteristics of Field Emitter Triodes",IEEE Trans. Electron Devices,38,2558(1991).

(3) J.Itoh and H.Hiroshima:"Fabrication and theoretical study of micro-size vertical vacuum triodes",Vacuum
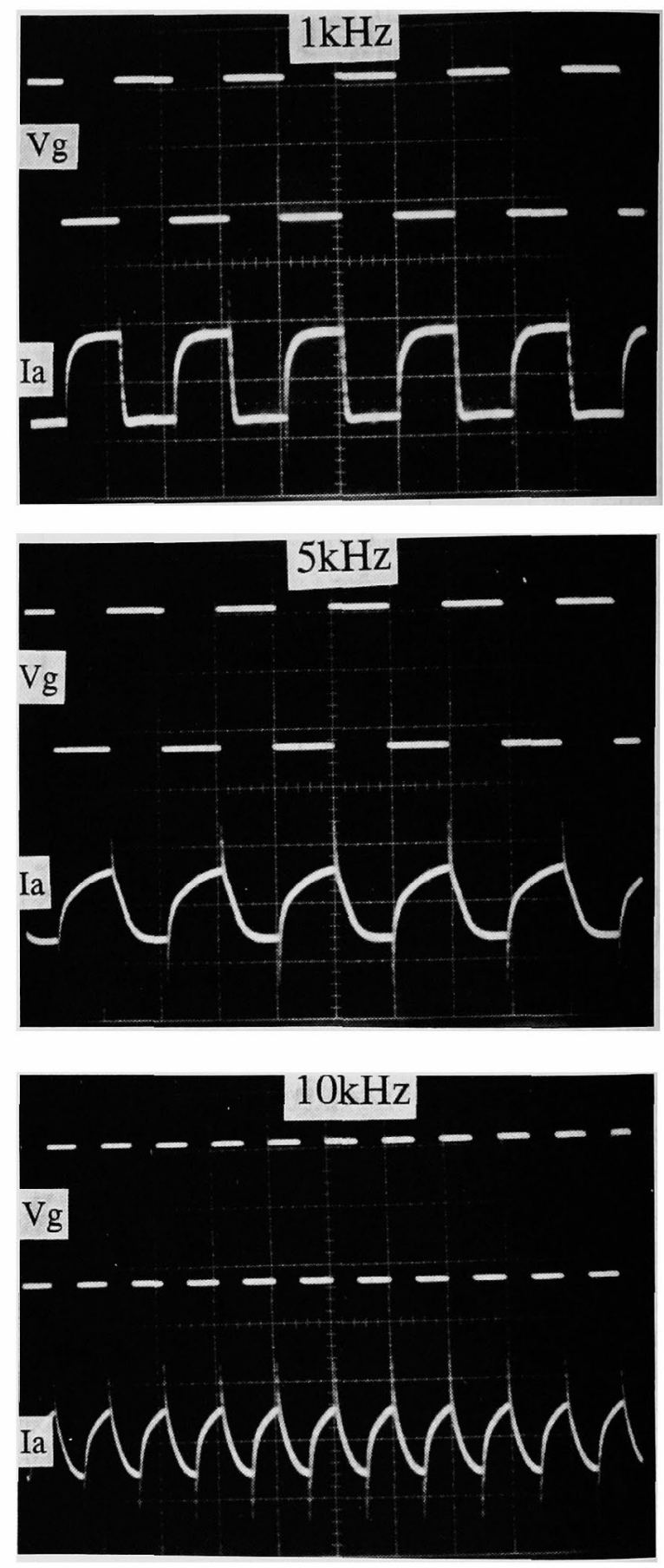

図 17 方形波パルス駆動による電子放出特性の実験結果

Fig.17. Experimental results for the pulse driving.

Microelectronics 89, ed.R.E.Turner,p.231 (IOP, Bristol, 1989).

(4) K.Betsui:"Fabrication and Characteristics of Si Field Emitter Arrays", Proc.4th Int. Conf. Vacuum Microelectronics,Nagahama,p.26(1991).

(5) H.F.Gray, J.L.Shaw, G.W.Jones and C.T.Sune:"High 
Current Density Silicon FEAs", Proc.4th Int. Conf. Vacuum Microelectronics,Nagahanna,p.84(1991).

(6) J.Itoh, K.Tsuburaya, S.Kanemaru, T.Watanabe and S.Itoh:" Fabrication and Characterization of CombShaped Lateral Field-Emitter Array", Jpn.J.Appl .Phys. ,32,1221(1993).

(7) Z.Huang, N.E.McGruer, and K.Warner:" 200-nm Gated Field Einitters",IEEE Electron Devices Lett. ,14,83(1993).

(8) H.H.Busta, J.E.Pogemiller and B.J.Zimmerman : "Emission Characteristics of Silicon Vacuum Triodes with Four Different Gate Geometries", IEEE Trans. Electron Devices ,40,1530(1993).

(9) G.Hashiguchi, H.Sakamoto, S.Kanazawa and H.Mimura : "Fabrication and emission characteristics of new wedge-shaped silicon emitters", Appl.Surf.Sci.,76/77,41(1994).

(10) G.Hashiguchi and H.Mimura:"New Fabrication Method and Electrical Characteristics of Conical Silicon Field Emitters",Jpn.J.Appl.Phys.,34,1493(1995).

(11) K.Yokoo, M.Arai, M.Mori, J.Bae and S.Ono:" Active control of the emission current of field emitter arrays", J.Vac.Sci.Technol.B13,491(1995).

(12) G.Hashiguchi and H.Fujita:"Monolithic Fabrication of Polycrystalline Silicon Field Emitters and Thin Film Transistor's", Technical Digest of the 13th Sensor Symposium,21(IEEJ, Tokyo, 1995).

(13) G.Hashiguchi, H.Mimura and H.Fujita:"Fabrication and Emission Characteristics of Polycrystalline Silicon Field Emitters",Jpn.J.Appl.Phys.,34,L883(1995).

（14）例えば、江刺正喜著：”半導体集積回路設計の基礎"、西 沢潤一編、(培風館、東京,1986)p.11
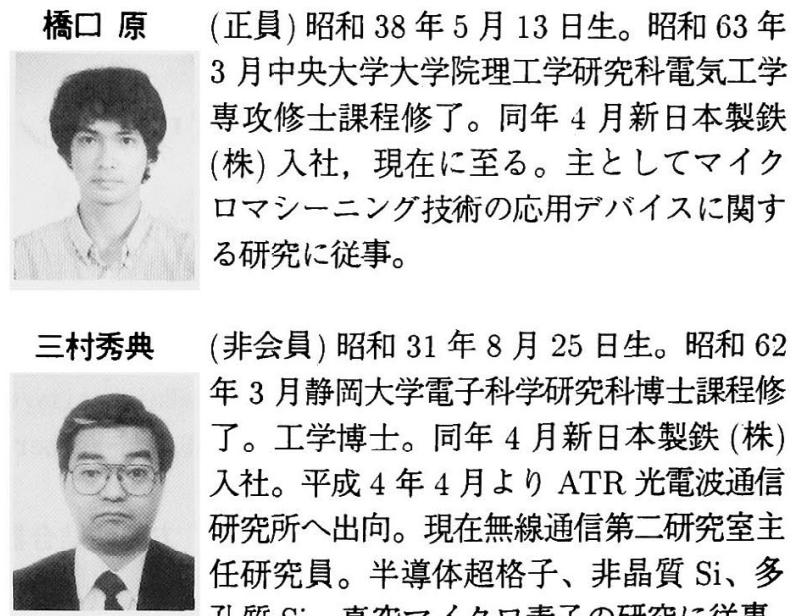

(非会員) 昭和 31 年 8 月 25 日生。昭和 62 年 3 月静岡大学電子科学研究科博士課程修 了。工学博士。同年 4 月新日本製鉄 (株) 入社。平成 4 年 4 月より ATR 光電波通信 研究所へ出向。現在無線通信第二研究室主 任研究員。半導体超格子、非晶質 $\mathrm{Si} 、$ 多 孔質 $\mathrm{Si}$ 、真空マイクロ素子の研究に従事。 IEEE、電子情報通信学会、応用物理学会、テレビジョン 学会、SID 会員。

藤田博之 (正員) 昭和 27 年 12 月 13 日生。昭和 50

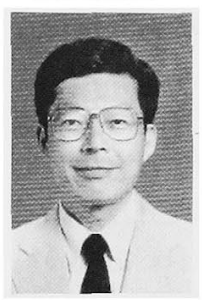
年 3 月東京大学電気工学科卒業。 52 年 3 月同大学院にて工学修士、55 年 3 月工学 博士。同年 4 月より東京大学生産技術研究 所講師、助教授を経て、平成 5 年 8 月よ り同教授。主としてマイクロエレクトロニ クスの研究に従事。 